\title{
UPAYA MENINGKATKAN KEAKTIFAN SISWA DI MASA PANDEMI COVID 19 MELALUI METODE PEMBELAJARAN TEAMS GAMES TOURNAMENT DI SMK NEGERI 1 SAPTOSARI
}

\author{
Nugroho Wibowo \\ SMK Negeri 1 Saptosari Gunungkidul \\ Corresponding Author: asyifahaifa3@gmail.com
}

\begin{abstract}
This study aims to increase student activeness in the Basic Competencies of Implementing Manual Transmission Maintenance Methods in Class XI TKR B SMK Negeri 1 Saptosari through the application of the Teams Games Tournament (TGT) learning method. This research is a Classroom Action Research (CAR) which consists of three cycles, each cycle consisting of four stages, namely: planning, implementing, observing and reflecting. The subjects of this study were class XI TKR B SMK Negeri 1 Saptosari in the academic year 2020/2021, totaling 32 students. Methods of data collection in this study using the method of observation and questionnaires, and the instruments used consisted of: observation sheets and questionnaires. The data analysis technique used in this research is descriptive quantitative analysis with a percentage. The indicators of success in this study were more than $75 \%$ of students were active in learning. Based on the results of the study, it can be concluded that the application of the TGT learning method can increase the overall activeness of students, the percentage of overall activeness is $79.43 \%$ of the maximum percentage, the average increase in learning activeness from cycle I to cycle II is $10.88 \%$ while from cycle II to cycle III of $13.76 \%$.
\end{abstract}

Key Words: Activeness, Covid 19, Teams Games Tournament (TGT)

\begin{abstract}
Abstrak
Penelitian ini bertujuan untuk meningkatkan keaktifan siswa pada Kompetensi Dasar Menerapkan Cara Perawatan Transmisi Manual di Kelas XI TKR B SMK Negeri 1 Saptosari melalui penerapan metode pembelajaran Teams Games Tournament (TGT). Penelitian ini merupakan Penelitian Tindakan Kelas (PTK) yang terdiri dari tiga siklus, setiap siklus terdiri dari empat tahapan yaitu: perencanaan, pelaksanaan, pengamatan dan refleksi. Subyek penelitian ini kelas XI TKR B SMK Negeri 1 Saptosari Tahun Ajaran 2020/2021 yang berjumlah 32 siswa. Metode pengumpulan data dalam penelitian ini menggunakan metode observasi dan angket, dan instrumen yang digunakan terdiri dari: lembar observasi dan angket. Teknik analisa data yang digunakan dalam penelitian ini menggunakan analisis deskriptif kuantitatif dengan prosentase. Indikator keberhasilan dalam penelitian ini sebesar lebih dari $75 \%$ siswa aktif dalam pembelajaran. Berdasarkan hasil penelitian dapat disimpulkan bahwa penerapan metode pembelajaran TGT dapat meningkatkan keaktifan siswa prosentase keaktifan secara keseluruhan sebesar 79,43\% dari prosentase maksimal, rata-rata peningkatan keaktifan belajar dari siklus I ke siklus II sebesar 10,88\% sedangkan dari siklus II ke siklus III sebesar 13,76\%.
\end{abstract}

Kata Kunci: Covid 19, Keaktifan, Teams Games Tournament (TGT)

\section{PENDAHULUAN}

Rendahnya mutu pendidikan khususnya pendidikan di sekolah kejuruan merupakan salah satu masalah yang dihadapi dunia pendidikan di Indonesia. Berdasarkan skor PISA (Programme for International Student Assessment) pada tahun 2018 untuk bidang sains Indonesia berada pada peringkat 70 dari 78 negara (Harususilo, 2019), hal tersebut menunjukkan bahwa mutu pendidikan kita masih tertinggal dari negara-negara lain. Salah satu masalah yang teridentifikasi adalah proses pembelajaran, yaitu masih mendominasinya metode 
pengajaran verbalistik atau ceramah yang dilakukan guru didalam kelas, sehingga proses pembelajaranya masih terpusat pada pengajar (teacher centered). Masalah tersebut mengakibatkan kemampuan berfikir siswa menjadi kurang berkembang, karena metode tersebut membuat siswa cenderung mempunyai tingkat keaktifan yang rendah dan kurang dalam kemampuan analisis terhadap masalah-masalah yang dihadapi.

Partisipasi aktif siswa sangat berpengaruh pada proses perkembangan berpikir, emosi, dan sosial. Menurut penelitian (Bambang et al., 2019) faktor-faktor yang mempengaruhi partisipasi belajar peserta didik SMK adalah: keberanian memberikan tanggapan, pemahaman peserta didik, keberanian menjawab pertanyaan, kemampuan menjelaskan, kemampuan menyimpulkan, dan kepercayaan diri untuk bertanya. Beberapa upaya yang dapat dilakukan guru dalam mengembangkan keaktifan belajar siswa dengan meningkatkan minat siswa, membangkitkan motivasi siswa, serta menggunakan media dalam pembelajaran. Menurut (Arifin \& Adhi, 2012) belajar aktif diperlukan oleh peserta didik untuk dapat menghasilkan hasil belajar yang maksimum, hal tersebut dapat diartikan bahwa kurang aktifnya siswa dalam suatu pembelajaran menyebabkan tingkat pemahaman materi yang diberikan guru menjadi rendah.

Keaktifan siswa semakin sulit diamati ketika sekolah melakukan proses pembelajaran di masa pandemi Covid 19 ini, dimana proses pembelajaran sepenuhnya dilakukan dengan sistem pembelajaran jarak jauh atau dengan metode dalam jaringan. Kebijakan pemerintah Indonesia untuk menekan dampak virus corona pada bidang pendidikan dengan menghilangkan kegiatan pembelajaran langsung dan menggantinya dengan pembelajaran dalam jaringan diambil untuk mengantisipasi penularan virus melalui kontak langsung antar manusia atau yang lebih sering didengar dengan cara menjaga jarak (social distancing). Dalam proses pembelajaran online yang dilakukan menuntut siswa untuk melakukan pembelajaran dengan menggunakan gawai atau telepon genggam (hand phone), komunikasi dilakukan melalui aplikasi WhatsApp (WA), Short Massage Service (SMS), video call ataupun aplikasi google classroom. Penggunaan teknologi informasi ini selain sebagai sarana komunikasi dalam kondisi pandemi juga dapat digunakan sebagai sarana untuk mengatasi permasalahan keterbatasan sarana prasarana di SMK ( Pambayun, Sofyan \& Haryana, 2020).

Permasalahan yang timbul pada pembelajaran jarak jauh berdasarkan observasi penulis pada minggu kelima pembelajaran yang dirasakan siswa berasal dari sarana prasarana yang tidak sama antar siswa dalam hal ini spesifikasi handphone yang dimiliki siswa, jaringan internet yang berbeda tiap daerah, dan kuota internet yang terbatas di lingkungan keluarga tingkat menengah kebawah. Masalah lain dari segi pembelajaran adalah menurunnya keaktifan siswa di kelas, data awal penelitian menunjukkan tidak semua siswa mengikuti pembelajaran, 
data diperoleh baru sebesar 80,86\% siswa yang mengikuti pembelajaran. Dari kegiatan bertanya sebagai salah satu indikator keaktifan menunjukkan bahwa pada lima minggu awal terdapat rata-rata 1 siswa yang bertanya dalam setiap pertemuanya, jika diprosentase sebesar 3,12\% dari jumlah siswa. Data lain menunjukkan bahwa setiap pertemuan rata-rata terdapat 11 anak yang menjawab pertanyaan guru melalui forum diskusi dalam aplikasi google classroom, atau jika diprosentase sebesar 34,86\% dari total 32 siswa. Keberhasilan pembelajaran jika dilihat dari ujian formatif yang telah dilakukan belum menunjukkan keberhasilan, dari data menunjukkan bahwa rata-rata pencapaian nilai sebesar 3,56 dengan pencapaian ketuntasan 18,75\% atau sebanyak 6 siswa dari 32 siswa di kelas XI TKR B.

Proses pembelajaran pada hakekatnya merupakan proses interaksi antara guru dengan siswa yang didalamnya berisi aktivitas peserta didik melalui berbagai interaksi dan pengalaman belajar yang dialami oleh keduanya. Keaktifan adalah kegiatan yang bersifat fisik maupun mental, yaitu berbuat dan berfikir sebagai suatu rangkaian yang tidak dapat dipisahkan (Sardiman, 2009). Macam aktifitas siswa dalam proses pembelajaran terbagi menjadi dua bagian, bagian pertama adalah aktifitas fisik dan yang kedua adalah aktifitas psikis. Menurut (Warsono \& Haryanto, 2014) pembelajaran aktif didefinisikan secara sederhana sebagai pembelajaran yang melibatkan siswa secara aktif dalam proses pembelajaran. Pembelajaran aktif terjadi pada saat anak aktif terlibat dalam pembelajaran dan peserta didik bertanggungjawab atas materi yang harus dikuasai. Siswa harus didorong untuk berfikir, menganalisis, membentuk opini, praktik dan mengaplikasikan hal-hal yang dipelajari.

Agar tercipta pembelajaran aktif guru harus merancang skenario pembelajaran yang tepat, rancangan pembelajaran terlebih dahulu harus disesuaikan dengan karakteristik peserta didik, selanjutnya guru harus merancang strategi dan perangkat pembelajaran yang sesuai dalam upaya pencapaian tujuan pembelajaran. Dengan belajar secara aktif siswa diajak turut aktif dalam proses pembelajaran baik secara aktifitas fisik ataupun mental. Aktifitas fisik adalah gerakan yang dilakukan siswa melalui gerakan anggota badan, gerakan membuat sesuatu, bermain maupun bekerja yang dilakukan oleh siswa di dalam kelas. Siswa sedang melakukan aktifitas psikis jika daya jiwanya bekerja sebanyak-banyaknya atau banyak berfungsi dalam rangka pembelajaran. Pentingnya keaktifan siswa dalam pembelajaran menurut (Mulyasa, 2002), pembelajaran dikatakan berhasil dan berkualitas apabila seluruhnya atau setidaktidaknya sebagian besar peserta didik terlibat secara aktif, baik fisik, mental maupun sosial dalam proses pembelajaran.

Aktifitas fisik dan mental harus terlihat dalam proses pembelajaran yang aktif, terdapat 8 macam aktifitas siswa dalam pembelajaran menurut Paul B. Diedrich dalam (Sardiman, 2009) 
yaitu: 1) Visual activities, yang termasuk didalamnya antara lain: membaca, memperhatikan gambar demonstrasi, percobaan dan pekerjaan orang lain; 2) Oral activities, terdiri dari: menyatakan, merumuskan, bertanya, memberi saran, mengeluarkan pendapat, mengadakan wawancara, diskusi dan interupsi; 3) Listening activities, berupa kegiatan mendengarkan: uraian, percakapan, diskusi, musik dan pidato; 4) Writing activities, misalnya menulis cerita, karangan, laporan, angket, dan menyalinnya; 5) Drawing activities, dapat diidentifikasi dengan kegiatan mengambar, membuat grafik, peta, atau diagram; 6) Motor activities, yang termasuk didalamnya adalah melakukan percobaan, membuat konstruksi, mereparasi, bermain, berkebun dan beternak; 7) Mental activities, sebagai contoh dapat dilakukan dengan kegiatan menanggapi, menginggat, memecahkan soal, menganalisis, membuat hubungan, dan mengambil keputusan; 8) Emotional activities, misalnya menaruh minat, merasa bosan, gembira, bersemangat, bergairah, berani, tenang atau gugup.

Hasil penelitian (Ningsih, 2018) keaktifan siswa yang rendah berpengaruh terhadap keberhasilan pembelajaran disuatu kelas, terdapat pengaruh positif antara keaktifan siswa dengan prestasi belajar dengan kontribusi sebesar $42,7 \%$, dengan kata lain siswa yang aktif cenderung mempunyai kemandirian belajar yang lebih baik dibanding dengan yang tidak aktif.

Strategi pembelajaran yang tepat dapat dilakukan dengan pemilihan metode pembelajaran yang sesuai dengan tujuan pembelajaran. Metode pembelajaran yang dipilih sebaiknya bersifat variatif sesuai dengan materi pelajaran, selain itu pendekatan metode pembelajaran kooperatif dan berpusat pada siswa (student centered) sebaiknya dipilih guru untuk membuat siswa menjadi lebih aktif. Menurut (Isjoni, 2009) pembelajaran kooperatif adalah suatu model pembelajaran yang saat ini banyak digunakan untuk mewujudkan kegiatan belajar mengajar yang berpusat pada siswa, terutama untuk mengatasi permasalahan yang ditemukan guru dalam mengaktifkan siswa. Lebih lanjut menurut Robert E Slavin dalam (Isjoni, 2009) disebutkan bahwa ada tiga hal pokok dalam pembelajaran kooperatif yaitu: penghargaan kelompok, pertanggungjawaban individu dan kesempatan yang sama untuk berprestasi.

Belajar dengan kerja sama (cooperative learning) dapat dilakukan dalam suasana yang menyenangkan, seperti dengan permainan atau game. Tipe pembelajaran kooperatif yang menggunakan permainan adalah pembelajaran Teams Games Tournament (TGT). Pembelajaran kooperatif tipe TGT merupakan jenis pembelajaran kooperatif dimana siswa setelah belajar dalam kelompok diadakan sebuah turnamen akademik, dalam turnamen tersebut siswa akan berkompetisi sebagai wakil-wakil dari kelompok mereka dengan anggota kelompok lainnya yang berkemampuan sama dan diakhir dari turnamen tersebut terdapat penghargaan bagi para pemenang.

Pembelajaran kooperatif tipe TGT adalah salah satu tipe pembelajaran kooperatif yang 
menempatkan siswa dalam kelompok-kelompok belajar yang beranggotakan 4 sampai 5 orang siswa yang memiliki kemampuan, jenis kelamin dan suku atau ras yang berbeda. (Slavin, 2005) menyatakan bahwa model pembelajaran kooperatif tipe TGT menggunakan permainan akademik. Dalam turnamen siswa bertanding mewakili timnya dengan anggota tim lain yang setara dengan kemampuan akademik berdasarkan kinerja sebelumnya. Lebih lanjut dijelaskan bahwa dalam model pembelajaran kooperatif tipe TGT yang diungkapkan Slavin, terdiri dari 5 komponen yaitu: 1) Presentasi kelas (class precentation), proses pemberian materi yang dilakukan oleh guru dan pemberian informasi tentang rencana kegiatan pembelajaran; 2) Belajar dalam kelompok (teams), fungsi utama dari kelompok adalah untuk lebih mendalami materi bersama teman satu kelompoknya, dan mempersiapkan anggota kelompok agar dapat bekerja dengan baik dan optimal pada saat permainan; 3) Permainan (games), games terdiri atas pertanyaan-pertanyaan yang dirancang untuk menguji pengetahuan siswa yang diperoleh saat presentasi kelas dan belajar kelompok, kebanyakan games terdiri dari pertanyaan-pertanyaan sederhana yang diberi nomor; 4) Pertandingan (tournament), turnamen adalah sebuah struktur disaat game berlangsung, biasanya berlangsung pada akhir minggu atau akhir unit, setelah guru memberikan presentasi di kelas dan tim telah melaksanakan kerja kelompok; 5) Penghargaan kelompok (team recognition), rata-rata poin kelompok yang diperoleh dari game dan turnamen akan digunakan sebagai penentu penghargaan kelompok. Jenis penghargaan sesuai dengan kriteria yang telah ditentukan, penghargaan kelompok dapat berupa hadiah, sertifikat, dan sebagainya.

Berdasarkan uraian di atas dapat disimpulkan bahwa seorang guru harus mampu memilih metode yang tepat dalam proses pembelajarannya, seorang guru harus mampu memilih metode pembelajaran yang tepat dalam mencapai tujuan pembelajaran, pemilihan yang tepat dapat membuat siswa mempunyai kemandirian belajar yang tinggi terutama pada masa pandemi Covid 19. Pemilihan metode pembelajaran dengan pendekatan kooperatif dan berpusat pada siswa menentukan keaktifan dikelas tersebut, sedangkan pembelajaran kooperatif tipe TGT merupakan jenis pembelajaran kooperatif yang banyak digunakan untuk meningkatkan keaktifan siswa.

Permasalahan yang dihadapi guru dalam pelaksanaan pembelajaran dapat diidentifikasi sebagai berikut: 1) Kurangnya variasi metode pembelajaran yang dilakukan guru dimasa pandemi Covid 19, sebagian besar guru melakukan pembelajaran dengan pemberian tugas mengerjakan soal sesuai materi ajarnya, menayangkan paparan dengan Microsoft Power Point atau men-download materi dari internet atau Youtube; 2) Rendahnya keaktifan siswa, kegiatan pembelajaran hanya dikikuti rata-rata $80,86 \%$ siswa, rata-rata hanya 1 siswa yang bertanya 


\section{Nugroho Wibowo}

dalam setiap pertemuan, jika diprosentase sebesar 3,12\% dari jumlah siswa. Data lain menunjukkan bahwa setiap pertemuan rata-rata terdapat hanya 11 anak yang menjawab pertanyaan guru melalui forum diskusi dalam aplikasi google classroom, atau jika diprosentase sebesar 34,86 \% dari total 32 siswa; 3) Rendahnya hasil belajar diidentifikasi dari rendahnya pencapaian rata-rata hasil belajar pada ujian formatif pada KD Memelihara Kopling sebesar 3,56 dengan pencapaian ketuntasan 18,75\% atau sebanyak 6 siswa dari 32 siswa.

Berdasarkan latar belakang di atas, permasalahan yang timbul dalam penelitian ini adalah: apakah penerapan metode Teams Games Tournament (TGT) dapat meningkatkan keaktifan belajar siswa pada Kompetensi Dasar Menerapkan Cara Perawatan Transmisi Manual di Kelas XI TKR B SMK Negeri 1 Saptosari?

\section{METODE}

Jenis penelitian ini termasuk dalam Penelitian Tindakan Kelas (PTK), dilakukan di SMK Negeri 1 Saptosari Gunungkidul. Penelitian ini dilaksanakan pada Bulan Oktober 2020 dengan obyek penelitian sebanyak 32 siswa kelas XI TKRB.

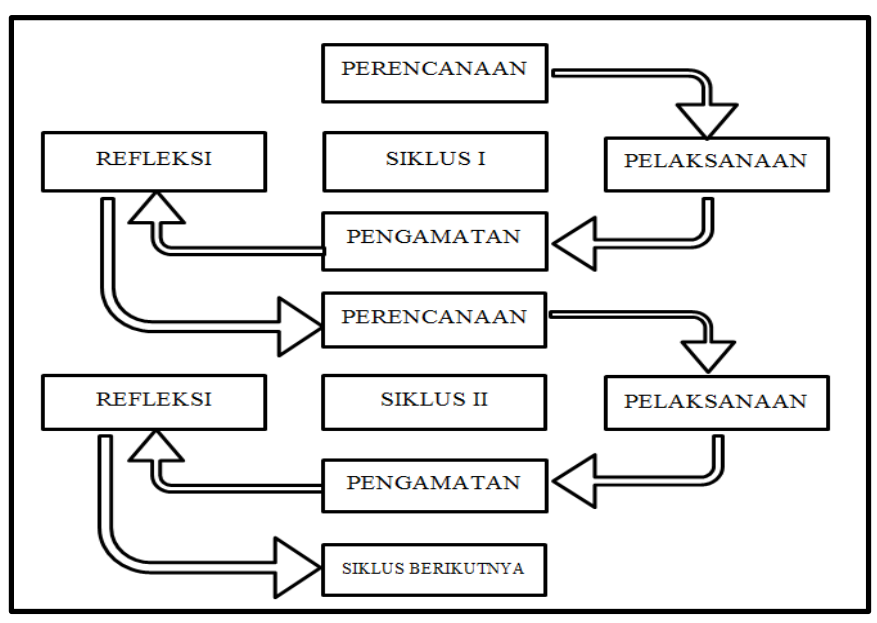

Gambar 1. Model Penelitian Tindakan Kelas (Suharsimi, 2006)

Metode pengumpulan data dalam penelitian ini menggunakan metode observasi dan angket. Data keaktifan belajar siswa digali setelah perlakuan metode pembelajaraan kooperatif tipe TGT pada kelas yang dilakukan perlakuan. Metode observasi dilakukan dengan mengamati langsung aktifitas belajar siswa di kelas jarak jauh dengan aplikasi Google Classroom dan grup WhatsApp (WA), dikarenakan pembelajaran dilakukan dengan pembelajaran jarak jauh. Peneliti selaku observer mengamati dan mencatat data keaktifan pada tiga macam aktifitas yang bisa diamati pada pembelajaran jarak jauh dan diskusi pada grup WA yaitu: oral activities, mental activities dan motor activities. Pengamatan dilakukan menggunakan lembar observasi yang sudah disiapkan sebelum pembelajaran dimulai.

Metode angket digunakan untuk melihat aktififitas pada lima macam aktifitas yang tidak bisa diamati menggunakan metode observasi langsung yaitu: listening activities, writing 
activities, drawing activities, visual activities, dan emotional activities. Angket dibagikan kepada siswa melalui kelas jarak jauh setelah tindakan dilakukan pada setiap siklusnya.

Penelitian ini direncanakan dalam dua siklus pada kompetensi dasar Menerapkan Cara Perawatan Transmisi Manual dengan materi jenis-jenis transmisi manual dan materi komponen dan cara kerja transmisi manual jenis syncromesh. Perencanaan setiap siklus terurai di bawah ini.

\section{Siklus I}

Studi pendahuluan dilakukan untuk mengetahui kondisi awal sebelum perlakuan pada siklus I dilakukan, data yang dihimpun meliputi: permasalahan yang ada didalam kelas meliputi: keaktifan siswa tentang kegiatan bertanya, masalah yang dihadapi selama pembelajaran jarak jauh, pembelajaran yang dilakukan oleh guru lain, rangking siswa dan hasil ujian formatif. Pada kegiatan perencanaan ini hal yang dilakukan adalah menyusun perangkat pembelajaran yang terdiri dari: skenario pembelajaran, Rencana Pelaksanaan Pembelajaran (RPP), dan menyiapkan media serta materi pembelajaran tentang Transmisi Manual dengan Microsoft Power Point yang didalamnya berupa gambar dan video, membuat soal yang akan digunakan sebagai soal turnamen pada siklus yang pertama dengan aplikasi Quizizz, membagi kelompok siswa menjadi 8 kelompok, dan menyusun alat pengumpul data berupa lembar observasi keaktifan belajar.

Kegiatan yang dilaksanakan pada tahap tindakan adalah melaksanakan kegiatan pembelajaran yang sudah direncanakan dalam skenario pembelajaran, memberikan soal latihan untuk persiapan turnamen yang akan dilakukan, memantau siswa berdiskusi melalui grup WA. Kegiatan selanjutnya adalah melaksanakan turnamen sesuai dengan pembagian kelompok yang sudah dibuat, setiap meja terdiri dari 8 orang yang mewakili setiap kelompok sesuai tingkatan yang sudah dibagi guru, turnamen dilakukan dengan mengerjakan soal pada aplikasi Quizizz. Terdapat empat turnamen sehingga semua siswa melaksanakan turnamen, kegiatan akhir pada tahap tindakan adalah mengumumkan hasil pelaksanaan turnamen untuk pemenang setiap turnamen dan pemenang kelompok, pemenang didapatkan dari hasil pengerjaan pada soal Quizizz.

Observasi dilakukan untuk melihat aktifitas siswa pada waktu pembelajaran kooperatif menggunakan tipe TGT melalui pembelajaran jarak jauh di kelas Google classroom dan diskusi kelompok grup WA, aktifitas diamati dengan lembar observasi dan data angket keaktifan, langkah selanjutnya guru mengumpulkan angket dengan aplikasi google form sebagai bahan analisis hasil belajar. Refleksi dilakukan untuk menganalisis hasil yang terjadi akibat perlakuan yang dilakukan, kegiatan ini berupa mencatat permasalahan yang terjadi selama pembelajaran, 
memaknai, menganalisis dan menyimpulkan hasil observasi keaktifan siswa dari lembar observasi. Catatan permasalahan yang terjadi, analisis hasil observasi dan kesimpulan pada siklus I digunakan sebagai dasar untuk merencanakan siklus II.

\section{Siklus II}

Hasil kegiatan refleksi pada siklus I digunakan sebagai dasar dalam perencanaan kegiatan di siklus II, rencana kegiatan pada siklus II yaitu perencanaan tindakan dengan penyusunan perangkat pembelajaran yang sudah diperbaiki berdasarkan analisis permasalahan pada siklus I dengan tahapan: membuat soal latihan tentang materi cara kerja transmisi manual jenis syncromesh yang akan digunakan sebagai bahan diskusi kelompok kecil, membuat soal yang akan digunakan sebagai soal turnamen pada siklus II dengan aplikasi Quizizz, menyiapkan alat pengumpul data berupa lembar observasi keaktifan belajar jarak jauh dan grup WA dan angket keaktifan belajar.

Kegiatan tindakan pada siklus II adalah melaksanakan kegiatan pembelajaran yang sudah direncanakan dalam skenario pembelajaran, kegiatan tersebut meliputi: melaksanakan kegiatan pembelajaran dengan Google Classroom, memberikan soal latihan untuk persiapan turnamen, selanjutnya siswa melaksanakan diskusi melalui grup WA dan guru memantau pelaksanaan diskusi dalam grup tersebut, melaksanakan turnamen pada siklus II sesuai dengan pembagian kelompok yang sudah dibuat, kegiatan terakhir adalah mengumumkan hasil pelaksanaan turnamen.

Observasi dilakukan untuk melihat aktifitas siswa pada waktu pembelajaran kooperatif menggunakan tipe TGT di kelas Google classroom dan diskusi kelompok grup WA, aktifitas diamati dengan lembar observasi dan pengisian angket melalui Google form, langkah selanjutnya guru mengumpulkan hasil tes Quizizz sebagai data untuk pemenang turnamen pada siklus II. Pengamatan dilakukan juga untuk mencermati apakah pelaksanaan pembelajaran sudah sesuai dengan skenario yang direncanakan pada siklus II, hasil pengamatan pada siklus II ini digunakan untuk menganalisis apakah hipotesis yang diajukan dalam penelitian ini sudah terbukti.

Tahapan analisis dan refleksi dilakukan untuk menentukan apakah diperlukan siklus lanjutan atau tidak dalam tujuan pembuktian hipotesa dalam penelitian ini, jika sudah terbukti maka siklus dihentikan pada siklus yang kedua, tetapi jika belum tercapai maka dilanjutkan dengan siklus selanjutnya. Kegiatan yang dilaksanakan pada tahap ini adalah membandingkan data observasi keaktifan belajar berdasarkan lembar observasi pada kelas Google Classroom dan grup WA serta angket keaktifan siswa antara siklus I dengan siklus II.

Hasil analisis dan refleksi perbandingan pada dua hal di atas digunakan sebagai dasar pembuatan kesimpulan pada siklus II, refleksi ini digunakan untuk mengetahui keberhasilan 
tindakan yang dilakukan terhadap masalah yang ada. Apabila indikator keberhasilan pada penelitian ini sudah tercapai maka siklus dihentikan sampai dengan siklus II dan selanjutnya akan dibuat laporan penelitian, akan tetapi jika siklus II belum memperlihatkan adanya kenaikan aktifitas dan hasil belajar pada kelas yang di beri perlakuan maka siklus akan dilanjutkan pada siklus III.

Teknik analisa data yang digunakan dalam penelitian ini menggunakan analisis deskriptif kuantitatif dengan prosentase. Data keaktifan belajar didapatkan melalui dua instrumen yaitu lembar observasi dan angket. Pada instrumen lembar observasi peneliti menghitung jumlah siswa yang melakukan aktifitas oral activities, mental activities dan motor activities, kemudian dilakukan prosentase terhadap komponen yang diamati selanjutnya membandingkan antara pra siklus, siklus I dan siklus II.

Sedangkan pada data angket untuk menggali lima aktifitas yaitu: listening activities, writing activities, drawing activities, mental activities, dan emotional activities dilakukan penskoran dengan memberikan skor 1 pada jawaban ya dan skor 0 pada jawaban tidak untuk pertanyaan/pernyataan yang bersifat positif serta skor 0 untuk jawaban ya dan skor 1 untuk jawaban tidak pada pertanyaan yang bersifat negatif. Setelah dilakukan penskoran selanjutnya dilakukan penhitungan prosentase keaktifan dan yang terakhir dilakukan analisis dengan membandingkan persentase pada siklus I dan siklus II.

Tindakan pada penelitian ini bertujuan untuk meningkatkan keaktifan belajar pada kompetensi dasar "menerapkan cara perawatan transmisi manual" melalui penerapan metode pembelajarn TGT. Kriteria keberhasilan pada penelitian ini adalah apabila penerapan metode TGT dapat meningkatkan keaktifan belajar siswa lebih dari 75\% dari jumlah siswa, mengacu pada (Mulyasa, 2008) bahwa dari segi proses, pembelajaran dikatakan berhasil dan berkualitas apabila seluruhnya atau setidak-tidaknya sebagian besar (75\%) siswa terlibat secara aktif dalam proses pembelajaran. Indikator di atas digunakan sebagai acuan dalam pelaksanaan penelitian ini, apabila kriteria tersebut sudah tercapai maka penelitian dapat dihentikan dan penelitian dinyatakan selesai..

\section{HASIL DAN PEMBAHASAN}

\section{Hasil}

Pra Siklus

Kondisi awal sebelum tindakan diamati oleh peneliti melalui observasi pembelajaran jarak jauh yang dilakukan, hasil observasi menunjukkan bahwa keaktifan siswa pada lima minggu awal terdapat rata-rata 1 siswa yang bertanya dalam setiap pertemuanya, jika diprosentase 
sebesar 3,12\% dari jumlah siswa. Data lain menunjukkan bahwa setiap pertemuan rata-rata terdapat 11 anak yang menjawab pertanyaan guru melalui forum diskusi dalam aplikasi Google Classroom, atau jika diprosentase sebesar $34,86 \%$ dari total 32 siswa.

Siklus I

Pelaksanaan tindakan siklus I dilaksanakan pada hari Rabu tanggal 07 Oktober 2020 dengan jumlah waktu pembelajaran 4 x 45 menit, pada jam ke 1 sampai dengan 4. Kegiatan observasi dilaksanakan bersamaan dengan pelaksanaan tindakan pada siklus I, guru mengamati perkembangan di Google Classroom dan grup WA selanjutnya mencatat hasil observasi di lembar observasi. Hasil observasi dapat dilihat pada tabel 1 berikut:

Tabel 1. Hasil Observasi Keaktifan Siswa pada Siklus I

\begin{tabular}{|c|c|c|c|}
\hline NO & KOMPONEN YANG DIOBSERVASI & \begin{tabular}{|l|} 
JUMLAH \\
SISWA
\end{tabular} & (\%) \\
\hline 1 & \multicolumn{3}{|l|}{ Oral activities } \\
\hline $\mathrm{a}$ & Jumlah siswa yang bertanya & 1 & 3,13 \\
\hline $\mathrm{b}$ & Jumlah siswa yang menyampaikan pendapat & 9 & 28,13 \\
\hline $\mathrm{C}$ & Jumlah siswa yang menjawab pertanyaan guru & 8 & 25,00 \\
\hline & \multicolumn{2}{|l|}{ Rata-rata } & 18,75 \\
\hline \multirow[t]{4}{*}{2} & Mental activities & & \\
\hline & $\begin{array}{l}\text { Jumlah siswa yang menjawab benar pertanyaan } \\
\text { guru }\end{array}$ & 8 & 25,00 \\
\hline & $\begin{array}{l}\text { Jumlah siswa yang menanggapi materi yang } \\
\text { diberikan guru }\end{array}$ & 9 & 28,13 \\
\hline & \multicolumn{2}{|l|}{ Rata-rata } & 26,56 \\
\hline 2 & \multicolumn{3}{|l|}{ Motor Activities } \\
\hline $\mathrm{a}$ & $\begin{array}{l}\text { Jumlah siswa yang siap dikelas sebelum } \\
\text { pembelajaran dimulai }\end{array}$ & 16 & 50,00 \\
\hline$b$ & Jumlah siswa yang hadir dikelas & 32 & 100,00 \\
\hline$c$ & $\begin{array}{l}\text { Jumlah siswa yang mengajak/memotivasi teman } \\
\text { lain untuk belajar/berdiskusi }\end{array}$ & 8 & 25,00 \\
\hline \multirow[t]{2}{*}{ d } & $\begin{array}{l}\text { Jumlah siswa yang menshare/mencari literatur } \\
\text { lain untuk belajar/diskusi kelompok }\end{array}$ & 2 & 6,25 \\
\hline & \multicolumn{2}{|l|}{ Rata-rata } & 45,31 \\
\hline
\end{tabular}

Sedangkan data angket untuk mengetahui lima macam aktifitas selain macam aktifitas yang digali dari data observasi dapat dilihat pada tabel berikut ini.

Tabel 2. Hasil Angket Keaktifan Siswa pada Siklus I

\begin{tabular}{|c|l|c|}
\hline NO & \multicolumn{1}{|c|}{ MACAM AKTIFITAS } & $\begin{array}{c}\text { Siklus 1 } \\
\text { (\%) }\end{array}$ \\
\hline 1 & Visual activities & 84,38 \\
\hline 2 & Listening activities & 81,25 \\
\hline 3 & Writing activities & 57,03 \\
\hline 4 & Emotional activities & 93,75 \\
\hline 5 & Draning activities & 31,25 \\
\hline
\end{tabular}

Aktifitas tertinggi pada emotional activities sebesar 93,75\% dan aktivitas terendah pada drawing activities sebesar 31,25\%, jika digabungkan data keaktifan siswa secara keseluruhan didapatkan rata-rata $54,78 \%$. 
Refleksi dari pelaksanaan tindakan pada siklus I bahwa besar persentase oral activities $18,75 \%$, mental activites $26,56 \%$, dan motor activities sebesar $45,31 \%$. Sedangkan jika dilihat dari data angket terlihat bahwa dari lima macam aktivitas, aktifitas tertinggi adalah emotional activities sebesar 93,75\%, dan aktivitas terendah adalah drawing activities sebesar 31,25\%. Sedangkan aktifitas lain: visual activities sebesar 84,38\%, listening activities $81,25 \%$, dan writing activities $57,03 \%$.

Jika dilihat dari indikator keberhasilan dalam penelitian ini terdapat 3 macam aktifitas yang sudah mencapai indikator yaitu: emotional activities, visual activities, listening activities dan terdapat 5 aktifitas yang belum mencapai batas tercapainya indikator keberhasilan sebesar $75 \%$ dari total siswa. Jika di rata-rata aktifitas siswa secara keseluruhan prosentasenya sebesar $54,78 \%$ dari seluruh siswa yang berjumlah 32 siswa, dan belum mencapai indikator keberhasilan dalam penelitian ini.

\section{Siklus II}

Pelaksanaan siklus II dilaksanakan pada hari Rabu tanggal 14 Oktober 2020 sesuai dengan jadwal pada pelajaran Chasis dan SPT jam ke 1-4. Hasil observasi pada pembelajaran jarak jauh dan pelaksanaan diskusi digrup WA, didapatkan data pada variabel keaktifan siswa terjadi kenaikan aktifitas siswa, terbukti dari data untuk oral aktivities naik 30,21\%, mental activities $20,31 \%$, dan motor activities naik sebesar $14,06 \%$, jika dirata-rata keaktifan siswa dari data observasi sebesar 51,73\%. Walaupun sudah mengalami kenaikan tetapi belum mencapai indikator keberhasilan dalam penelitian ini.

Tabel 3. Hasil Observasi Keaktifan Siswa pada Siklus II

\begin{tabular}{|c|c|c|c|c|c|}
\hline \multirow[b]{2}{*}{ NO } & \multirow[b]{2}{*}{ KOMPONEN YANG DIOBSERVASI } & \multicolumn{2}{|c|}{ SIKLUS I } & \multicolumn{2}{|c|}{ SIKLUS II } \\
\hline & & $\begin{array}{l}\text { JUMLAH } \\
\text { SISWA }\end{array}$ & (\%) & $\begin{array}{l}\text { JUMLAH } \\
\text { SISWA }\end{array}$ & (\%) \\
\hline 1 & Oral activities & & & & \\
\hline $\mathrm{a}$ & Jumlah siswa yang bertanya & 1 & 3,13 & 11 & 34,38 \\
\hline$b$ & Jumlah siswa yang menyampaikan pendapat & 9 & 28,13 & 13 & 40,63 \\
\hline $\mathrm{c}$ & Jumlah siswa yang menjawab pertanyaan guru & 8 & 25,00 & 23 & 71,88 \\
\hline & Rata-rata & & 18,75 & & 48,96 \\
\hline 2 & Mental activities & & & & \\
\hline $\mathrm{a}$ & $\begin{array}{l}\text { Jumlah siswa yang menjawab benar pertanyaan } \\
\text { guru }\end{array}$ & 8 & 25,00 & 17 & 53,13 \\
\hline$b$ & $\begin{array}{l}\text { Jumlah siswa yang menanggapi materi yang } \\
\text { diberikan guru }\end{array}$ & 9 & 28,13 & 13 & 40,63 \\
\hline & Rata-rata & & 26,56 & & 46,88 \\
\hline 2 & Motor Activities & & & & \\
\hline $\mathrm{a}$ & $\begin{array}{l}\text { Jumlah siswa yang siap dikelas sebelum } \\
\text { pembelajaran dimulai }\end{array}$ & 16 & 50,00 & 25 & 78,13 \\
\hline$b$ & Jumlah siswa yang hadir dikelas & 32 & 100,00 & 32 & 100,00 \\
\hline$c$ & $\begin{array}{l}\text { Jumlah siswa yang mengajak/memotivasi teman } \\
\text { lain untuk belajar/berdiskusi }\end{array}$ & 8 & 25,00 & 15 & 46,88 \\
\hline $\mathrm{d}$ & \begin{tabular}{|l|} 
Jumlah siswa yang menshare/mencari literatur \\
lain untuk belajar/diskusi kelompok
\end{tabular} & 2 & 6,25 & 4 & 12,50 \\
\hline & Rata-rata & & 45,31 & & 59,38 \\
\hline
\end{tabular}


Sedangkan pada data angket pada lima aktifitas lain menunjukkan data sebagai berikut:

Tabel 4. Hasil Angket Keaktifan Siswa pada Siklus II

\begin{tabular}{|c|l|r|c|}
\hline NO & \multicolumn{1}{|c|}{ MACAM AKTIFITAS } & $\begin{array}{c}\text { Siklus 1 } \\
\text { (\%) }\end{array}$ & \multicolumn{1}{c|}{$\begin{array}{c}\text { Siklus 2 } \\
\text { (\%) }\end{array}$} \\
\hline 1 & Visual activities & 84,38 & 90,10 \\
\hline 2 & Listening activities & 81,25 & 80,42 \\
\hline 3 & Writing activities & 57,03 & 68,32 \\
\hline 4 & Emotional activities & 93,75 & 93,75 \\
\hline 5 & Draming activities & 31,25 & 37,50 \\
\hline
\end{tabular}

Skor tertinggi masih pada aktifitas emotional activities sebesar 93,75\% dan terendah pada drawing activities sebesar 37,50\% dari prosentase maksimal, jika digabungkan maka diperoleh data rata-rata keaktifan menjadi $65,66 \%$.

Aktifitas yang dilihat dari data angket memberikan data bahwa terjadi kenaikan sebesar 4,49\% menjadi 74,02\%. Terdapat 3 aktifitas yang naik yaitu: visual activities 90,10\%, writing activities 68,32\% dan drawing activities sebesar 37,50\%. Satu aktifitas yang tetap yaitu emotional activities sebesar 93,75\% dan satu aktifitas yang turun yaitu listening activities sebesar $80,42 \%$. Secara keseluruhan rata-rata keaktifan menjadi $65,66 \%$ dan belum mencapai indikator keberhasilan dalam penelitian ini.

\section{Siklus III}

Pelaksanaan siklus III dilaksanakan selama dua hari yaitu pada tanggal 21 dan 23 Oktober 2020 dihari Rabu dan Jumat jam ke 1-4. Pembelajaran dilakukan dengan tatap muka dengan jumlah siswa 16 anak setiap pertemuannya dan tetap melakukan protokol pencegahan Covid 19. Dalam pembelajaran praktik yang dilakukan observer melakukan pengamatan dan menuliskan dalam lembar observasi, lembar observasi ditambahkan 5 macam aktifitas yang ketika tatap muka dapat diamati langsung oleh observer, maka angket keaktifan siswa tidak digunakan lagi. Data hasil observasi terurai di bawah ini:

Tabel 5. Data Keaktifan Siswa pada Siklus III

\begin{tabular}{|c|c|c|c|c|}
\hline NO & MACAM AKTIFITAS & $\begin{array}{c}\text { Siklus } 1 \\
(\%)\end{array}$ & $\begin{array}{c}\text { Siklus } 2 \\
(\%)\end{array}$ & $\begin{array}{c}\text { Siklus } 3 \\
(\%)\end{array}$ \\
\hline 1 & Oral activities & 18,75 & 48,96 & 71,88 \\
\hline 2 & Mental activities & 26,56 & 46,88 & 78,13 \\
\hline 3 & Motor Activities & 45,31 & 59,38 & 76,56 \\
\hline 4 & Visual activities & 84,38 & 90,10 & 82,29 \\
\hline 5 & Listening activities & 81,25 & 80,42 & 81,25 \\
\hline 6 & Writing activities & 57,03 & 68,32 & 88,54 \\
\hline 7 & Emotional activities & 93,75 & 93,75 & 95,83 \\
\hline 8 & Drawing activities & 31,25 & 37,50 & 60,94 \\
\hline & Rata-rata & 54,79 & 65,66 & 79,43 \\
\hline
\end{tabular}

Refleksi yang dapat dilakukan berdasarkan data pada siklus III adalah berdasarkan data keaktifan siswa pada siklus III menunjukan bahwa keaktifan siswa secara keseluruhan 
mencapai rata-rata 79,43\% dari prosentase maksimal. Data keaktifan siswa tertinggi pada writing activities sebesar 88,54\% dan data terendah pada drawing activities sebesar 60,94\%.

Berdasarkan data keaktifan siswa pada siklus I, II dan III disimpulkan bahwa indikator keberhasilan dalam penelitian ini telah terpenuhi. Dari data keaktifan siswa menunjukkan prosentase keaktifan siswa sebesar $79,43 \%$ dan sudah melebihi indikator keaktifan siswa sebesar $\geq 75,00 \%$. Berdasarkan data di atas selanjutnya dilakukan analisis keberhasilan tindakan, dapat disimpulkan bahwa tindakan yang dilakukan telah berhasil dan tindakan dapat dihentikan.

\section{Pembahasan}

Tujuan dari penelitian ini untuk mengetahui peningkatan keaktifan pada kompetensi dasar Menerapkan Cara Perawatan Transmisi Manual setelah diberikan tindakan pengunaan metode pembelajaran TGT. Metode pembelajaran TGT terdiri dari lima tahapan yaitu: presentasi kelas, diskusi, permainan, turnamen dan penghargaan tim, metode pembelajaran ini termasuk kedalam kelompok pembelajaraan kooperatif dimana proses pembelajaran dilakukan bersama-sama dimana pembelajaran berpusat pada siswa dan guru berfungsi sebagai fasilitator.

Berdasarkan data keaktifan siswa yang digali dari dua instrumen yaitu lembar observasi dan angket didapatkan data bahwa terjadi peningkatan keaktifan siswa jika dilihat berdasarkan rata-rata 8 macam aktifitas yaitu: visual activities, oral activities, listening activities, writing activities, drawing activities, motor activities, mental activities, dan emotional activities.

Prosentase keaktifan secara keseluruhan sebesar 79,43\% dari prosentase maksimal dan sudah memenuhi kriteria keberhasilan dalam penelitian ini. Rata-rata peningkatan keaktifan belajar dari siklus I ke siklus II sebesar 10,88\% sedangkan dari siklus II ke siklus III sebesar 13,76\%. Kenaikan tertinggi dari siklus I, II, III terlihat pada oral activities sebesar 53,13\%, sedangkan terjadi penurunan pada visual activities sebesar 2,09\% dari siklus I,II dan ke III. Peningkatan keaktifan dari siklus I, II dan III dapat dilihat di bawah ini.

Tabel 6. Data Kenaikan Keaktifan Siswa

\begin{tabular}{|c|l|c|c|}
\hline NO & MACAM AKTIFITAS & $\begin{array}{c}\text { Selisih Siklus } \\
\text { I ke II }\end{array}$ & $\begin{array}{c}\text { Selisih Siklus } \\
\text { II ke III }\end{array}$ \\
\hline 1 & Oral activities & 30,21 & 22,92 \\
\hline 2 & Mental activities & 20,31 & 31,25 \\
\hline 3 & Motor Activities & 14,06 & 17,19 \\
\hline 4 & Visual activities & 5,72 & $-7,81$ \\
\hline 5 & Listening activities & $-0,83$ & 0,83 \\
\hline 6 & Writing activities & 11,29 & 20,22 \\
\hline 7 & Emotional activities & 0,00 & 2,08 \\
\hline 8 & Draning activities & 6,25 & 23,44 \\
\hline \multicolumn{2}{|c|}{ Rata-rata } & $\mathbf{1 0 , 8 8}$ & $\mathbf{1 3 , 7 6}$ \\
\hline
\end{tabular}


Pada siklus terakhir aspek emotional activities merupakan aktifitas tertinggi dengan prosentase 95,83\% sedangkan drawing activities merupakan aktifitas terendah dengan prosentase sebesar $60,94 \%$. Data di atas jika ditampilkan dalam bentuk grafik terlihat pada gambar di bawah ini.

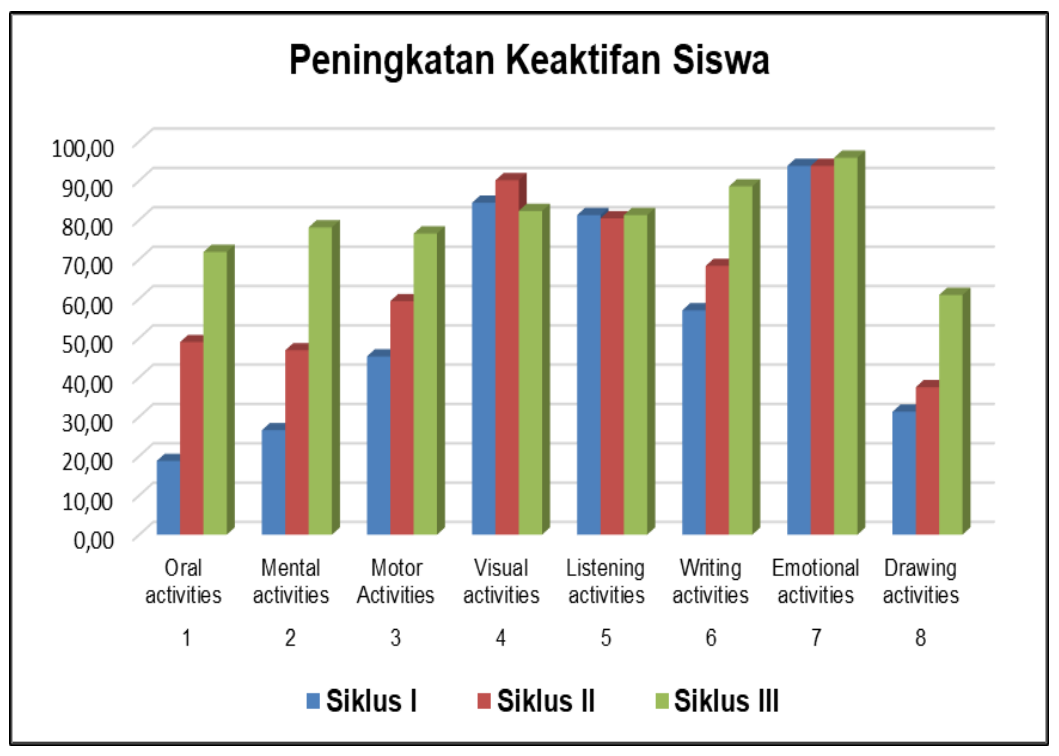

Gambar 2. Grafik Peningkatan Keaktifan Siswa

Berdasarkan data di atas dapat disimpulkan bahwa pemberian tindakan dengan menggunakan metode pembelajaran TGT terbukti dapat meningkatkan keaktifan siswa di kelas XI TKR B SMK Negeri 1 Saptosari pada kompetensi dasar "menerapkan cara perawatan transmisi manual".

\section{SIMPULAN}

Berdasarkan penelitian yang dilakukan dapat disimpulkan bahwa penerapan metode pembelajaran Teams Games Tournament (TGT) dapat meningkatkan keaktifan siswa pada Kompetensi Dasar Menerapkan Cara Perawatan Transmisi Manual, prosentase keaktifan secara keseluruhan sebesar 79,43\% dari prosentase maksimal, rata-rata peningkatan keaktifan belajar dari siklus I ke siklus II sebesar 10,88\% sedangkan dari siklus II ke siklus III sebesar 13,76\%.

Peneliti memiliki saran bagi guru yang akan menerapkan metode pembelajaran Teams Games Tournament (TGT) sebagai berikut, 1) memberi penjelasan awal yang cukup agar siswa tidak mengalami kebingungan dalam turnamen sehingga jalannya tindakan dapat berjalan lancar; 2) memantau jalannya diskusi dengan cermat, karena diskusi yang baik akan menjadikan kelompok siap untuk bertanding di turnamen sekaligus menciptakan kemandirian belajar. 


\section{DAFTAR PUSTAKA}

Arifin, Z., \& Adhi, S. (2012). Pengembangan Pembelajaran Aktif dengan ICT. Skripta Media Creative.

Bambang, D., Ginanjar, E. G., \& Sriyono. (2019). Faktor-Faktor Yang Mempengaruhi Rendahnya Partisipasi Belajar Peserta Didik Smk. Journal of Mechanical Engineering Education, 6(2), 206-219. https://doi.org/10.17509/jmee.v6i2.21797

Harususilo, Y. E. (2019). Skor PISA 2018: Peringkat Lengkap Sains Siswa di 78 Negara, Ini Posisi Indonesia". Kompas.Com, 1.

Isjoni. (2009). Pembelajaran Kooperatif: Meningkatkan Kecerdasan Komunikasi Antar Peserta Didik. Pustaka Pelajar.

Mulyasa. (2002). Manajemen Berbasis Sekolah: Konsep, Strategi dan Implementasi. Remaja Rosda Karya.

Mulyasa. (2008). Menjadi Guru Profesional Menciptakan Pelajaran Kreatif dan Menyenangkan. Remaja Rosda Karya.

Ningsih, A. (2018). Pengaruh Keaktifan Siswa Terhadap Hasil Belajar Ekonomi Kelas X di SMAN 2 Gunung Sahilan. Jurnal Pendidikan Ekonomi Akuntansi FKIP UIR, 6(2), 6166.

Pambayun, N. A. Y., Sofyan, H., \& Haryana, K. (2020, December). Vocational High School Infrastructure Conditions and The Challenges in Facing The Era of Literation and Industrial Revolution 4.0. In Journal of Physics: Conference Series (Vol. 1700, No. 1, p. 012068). IOP Publishing.

Sardiman. (2009). Interaksi dan Motivasi Belajar Mengajar. Rajawali Press.

Slavin, R. E. (2005). Cooperative Learning, Teori Riset dan Praktik. Nusa Media.

Suharsimi, A. (2006). Prosedur Penelitian, Suatu Pendekatan Praktek. Erlangga.

Warsono, \& Haryanto. (2014). Pembelajaran Aktif. Remaja Rosda Karya. 
34 Nugroho Wibowo

Jurnal Pendidikan Vokasi Otomotif, Vol 3, Nomor 2, Mei 2021 